\title{
Raising the Level of Awareness of Local Communities in Elaborating the Management Plan for Natura 2000 ROSCI Somesul Rece Site
}

\author{
Marian PROOROCU ${ }^{1}$, Ioan Gheorghe OROIAN ${ }^{1}$, Antonia ODAGIU ${ }^{1}$, Ecaterina PAULIUC ${ }^{*}$, Andreea BILC ${ }^{1}$ \\ ${ }^{1}$ University of Agricultural Science and Veterinary Medicine Cluj - Napoca, Manastur Street, \\ No. 3 - 5,400372 Cluj-Napoca, Romania' Tel.: +40264596384; Fax: +40 264593792 \\ *Corresponding author: sinzianapauliuc@yahoo.com
}

Bulletin USAMV series Agriculture 72(2)/2015

Print ISSN 1843-5246; Electronic ISSN 1843-5386

DOI 10.15835/buasvmcn-agr: 11732

\begin{abstract}
By implementating the management-plan for the ROSCI0233 Someşul Rece Site, it aims on one hand to preserve the habits and the species of community interes within the site, as well as to preserve the sustainable development of the area. In order to implement these objectives, it is necessary the involvement of the interested factors and collaboration with the local communities. Raising the level of information of local communities was achivied on 14 meetings, 2 in each of Somesul Rece Site 7 villages: Valea Ierii, Caps, Cerc, Plopi, Răcătău, Măguri and Muntele Rece. Following the meetings, two major informations were identified: on one hand, the lack of knowledge related to the protected areas, and on the other hand, people fear in terms of the existence of Natura 2000 protected areas in their zone. Analyzing the 2013 and 2015 questionnaires, we could observe the raising of awareness within the local communities on all the important aspects concerning the elaboration of Somesul Rece management plan: genaral informations about the site, benefits of the site, source of information on Natura 2000 Network etc. Raising the level of information of local communities within Nataura 2000 Somesul Rece Site was achived, helping also in elaborating the management plan of the area, even if the two important villages had a different view for the importance of the area: the inhabits within Valea Ierii were interested of the benefits of the area, but the inhabits within Maguri Racatau were not pleased at all of the fact that they are living in or near a protected site.
\end{abstract}

Keywords: Awareness, interested factors, questionnaires, protected areas, sustainable development

\section{INTRODUCTION}

Regardless the specific features of each project, the importance of developing a management plan for a Natura 2000 site is generally the same, namely, a practical instrument applied by custodians or the administration of a protected area.

The project is co-financed by the European Regional Development Fund under the Sectoral Operational Programme "Environment" (SOP), 4 Axis, Implementation of adequate management systems for nature protection.
The aim of the project is to build a base to support a favorable conservation status for the habitats and species of community interest witnin ROSCI0233 Somesul Rece site, involving all stakeholders. Because of its location in the Alpine biogeographical region, is specific for the grassland and coniferous forest.ecosystems.

The Natura 2000 Somesul Rece Site (8529 ha) is located in Transilvania, North West Development Region 6, in the southern part of Cluj County, an area that groups together a complex ecosystems 


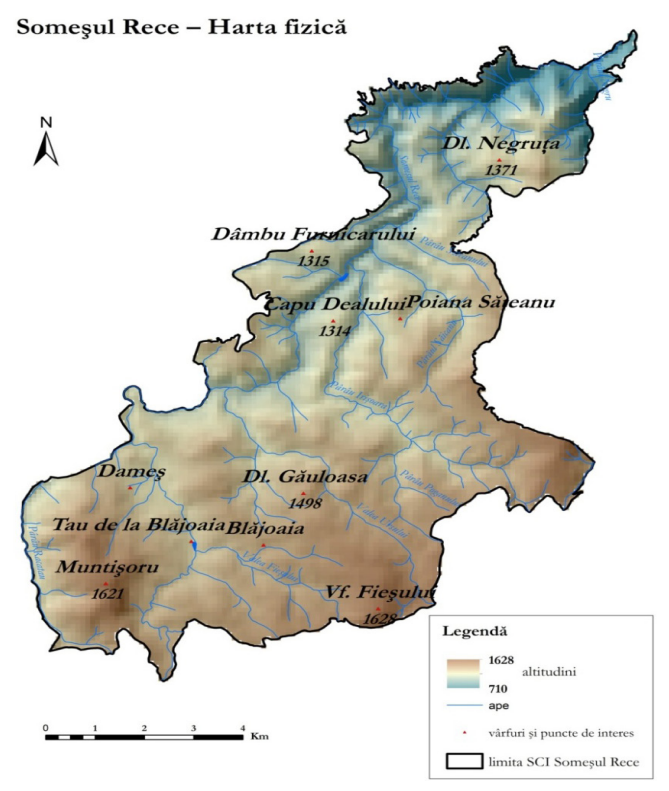

Fig. 1. Physical map of the ROSCI0233 Somesul Rece Site

(source: Management Plan for Somesul Rece Site)

with a dowry and a natural landscape of great beauty, variety and balance (Fig. 1).

The stages of Sustenable development Natura 2000 ROSCI0233 Somesul Rece Site project included:

- Natura 2000 ROSCI0233 Someșul Rece description

- Inventory, assessment and mapping of habitats and species of community interest in the site

Elaborating of Someșul Rece management plan, by:

- raising the level of awareness of local communities

and consulting the factors wich are interested in elaborating the management plan

- information and publicity for the project

\section{MATERIALS AND METHODS}

At the beginning and end of the awareness campaign, a awareness assessment was realized so that it can determine the impact of the carried out campaign. Thus, both at the beginning and end of the project, questionnaires were applied to the local population, questionnaires designed to show the level of information on Natura 2000 ROSCI0233 Somesul Rece Site. The research methodology used had a margin of error of $2 \%$. Sociological investigation was conducted on a representative sample of the target area , comprising about 100 randomly selected people within the local population. The data contained in the questionnaires were entered into a computer database and were statistically processed and presented in the form of statistical indicators illustrative for the level of awareness.

Evaluation work for the level of awareness took place:

- October - November, 2013 - the development, implementation and interpretation of pre-work questionnaires awareness of communities (in all 7 localities);

- June - April, 2013 - the application and interpretation of questionnaires after community awareness activities.

In order to develop human community mentality, two meetings were performed within the population in or near the protected area: Valea Ierii, Caps, Cerc, Plopi, Răcătău, Măguri and Muntele Rece. These meetings were held in specific locations where people could have access and which they were familiar: town hall, cultural center and schools.

All meetings were held under the same template. First, informative materials in the form of power-point presentations, brochures and various posters were presented and after this presentation, the audience had the opportunity to ask questions. The topics treated in early meetings refer to general elements of the Natura 2000 European Ecological Network, the potential benefits for local communities derived from the existence of Natura 2000 Sites, and a general characterization of the Natura 2000 Someșul Rece Site.

In 2015, two general meetings ware organized in Măguri Răcătău and Valea Ierii, for stakeholder consultation on the management plan draft.

The role of these meetings was to involve stakeholders directly affected by the presence namely the Natura 2000 Site: owners and land users, companies involved in the exploitation of local resources, tourism operators and local and county authorities.

\section{RESULTS AND DISCUSSION}

The questionnaire conducted in 2013 and 2015, included 14 questions with multiple choice answers. We will analize 12 of this 14 questions. These questions followed on the one hand the level of knowledge of the project in question, and on the other hand included sociodemographic questions whose role was to provide basic elements linking 
the information to categories they belong. A total of 150 questionnaires were completed, but only 120 were valid. The first question in the questionnaire referred to information about the project itself, and here , $80 \%$ of respondents have chosen the answer not respond , $13 \%$ showed their familiarity to the project, while $7 \%$ admitted that they had no knowledge of this concept. In 2015, $63 \%$ said they are familiar with this project, $20 \%$ have chosen I do not answer while $17 \%$ admitted that they are not at all familiar with this topic. Comparative analysis of the results show major changes in mentality.

\section{You know that within your commune there is a protected natural area wich is of European interest- Natura 2000 Someşul Rece Site?}

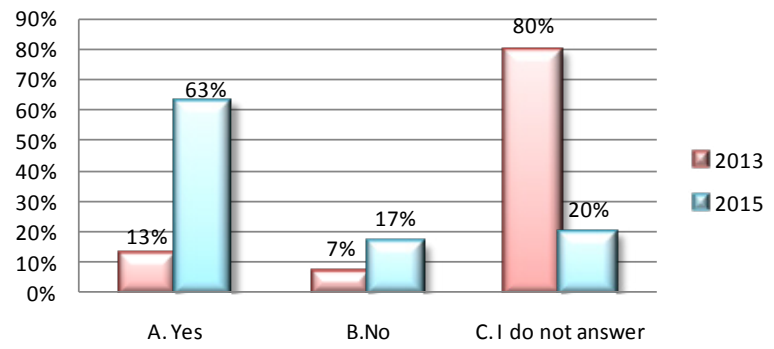

Regarding the sources of information, it can be observed a diversification of responses. 26\% of respondents found the necessary information from the meetings in villages, the percentage of those who found information on the project in question from posters and leaflets increased from 0 to $17 \%, 7 \%$ of respondents learned about the project from local authorities, from discussions with friends, $17 \%$ learned more project issues, $4 \%$ had other sources of information and $1 \%$ said that they heard about the project from mass-media.

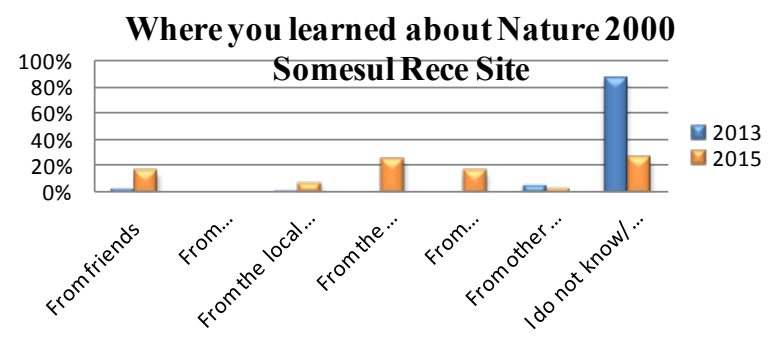

The third question related to the localities included in the project, reveals quite well the difference in answers between the two investigations. At the second inquest, it increased by 49 percent the number of subjects who responded to this question correctly and in opposition, declined by $30 \%$ the number of those who did not responded correctly and decreased by $11 \%$ the number of those who have chosen the option I do not know/I do not answer.

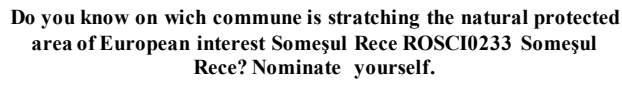
Rece? Nominate yourself.

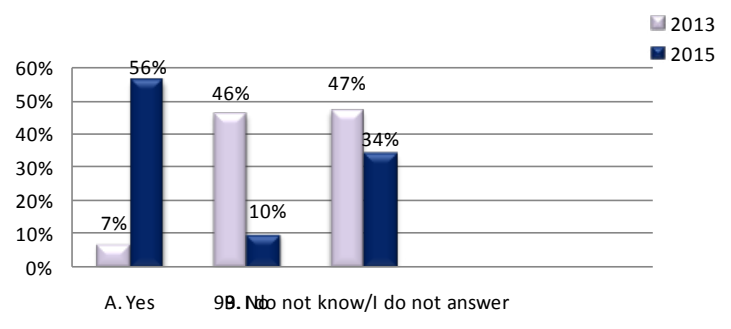

At the 4 question, the number of those who chose option yes increased significantly so, the percentage who learned about Natura 2000 increased from 11 to $65 \%$. The percentage of those who replied negatively to this question is $17 \%$, but the rate of those who choose I do not know/ I do not answer, radically decreased from $75 \%$ to $18 \%$.

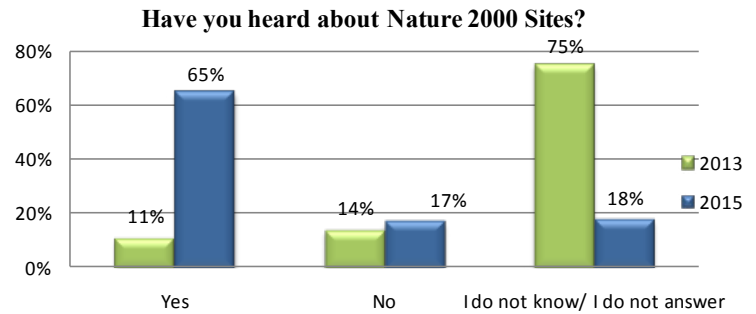

Compared with the 2013 inquery, it increased by $38 \%$ the percentage of those who declare themselves informed and with 13\%, the number oh those who are well informed. The problem that remains is relateing to the high number of those who are not informed or refuse to answer and they are $46 \%$ of those questioned.

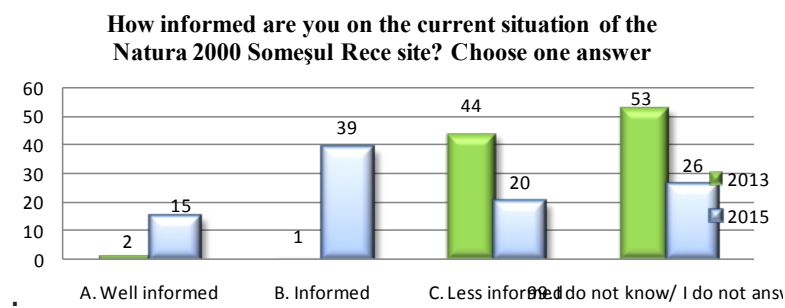

Question 7, regarding on the usefulness of an information campaign about the protected species within the site, it shows that people are willing to learn more informations about the natural 
protected area Somesul Rece, especially after information campaigns were conducted in the area.

\section{Believesit would be useful to know more about zones and protected species of plants and animals from natural protected area Somesul Rece?}

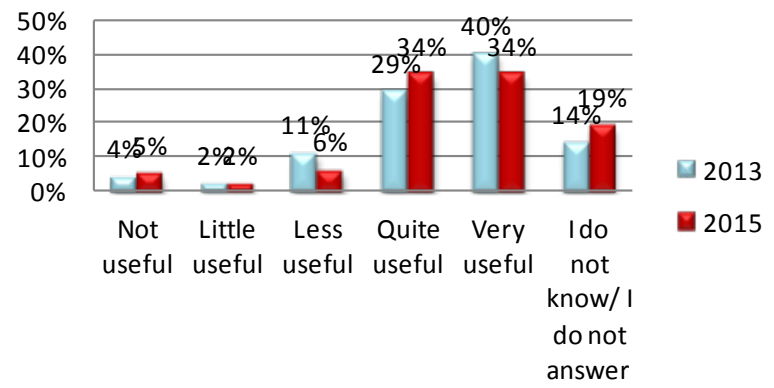

Regarding the areas protected by the Natura 2000 Somesul Rece Site , 65 \% of respondents were able to choose the correct option " meadows, forests, species of wildlife, fish and invertebrates ", compared with results from 2013 when only $18 \%$ choose this variant. We could not see a cangeover in relations to other variants, but the number of those questioned who choose option I do not know/I do not answer fell more than half.

Do you know what Nature 2000 Somesul Rece Site is protecting?

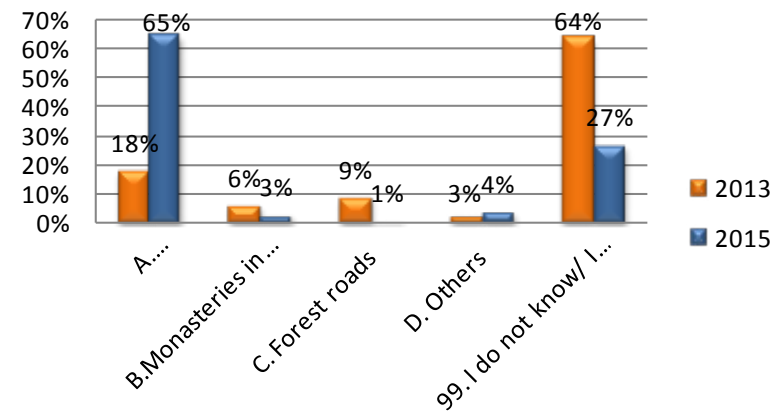

The ninth question wanted to establish the significance of the protection of natural areas and here, about $59 \%$ of the respondents consider this a priority and there is a decrease in the number of those who consider important nature but believe that certain issues should have priority and this rapport is from $45 \%$ to $19 \%$. Also is a growing number of those who consider as impediment the protected area - from $1 \%$ to $11 \%$ and from $1 \%$ to $3 \%$, the percentage of those who do not have a good opinion related to nature.

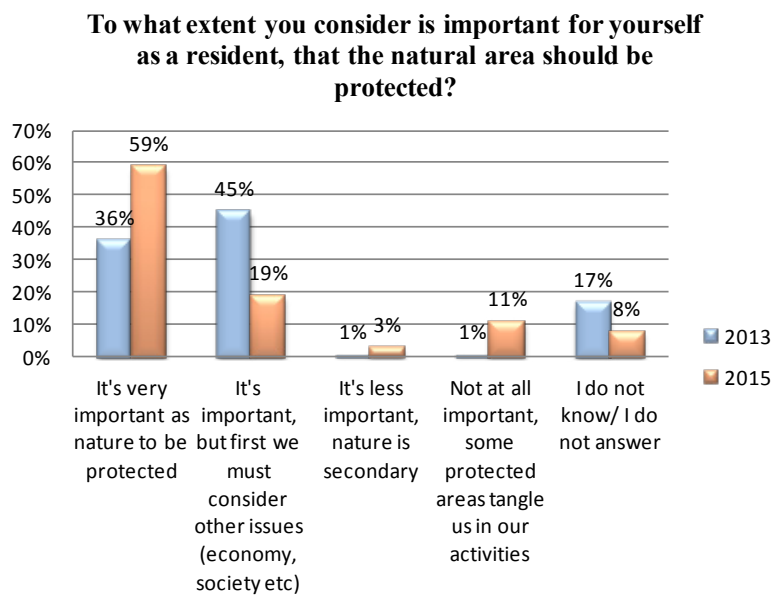

Question number ten wants to see the people perception regarding influence on lifestyle by stopping actions that endanger species and habitats at the site. Surprisingly, $51 \%$ gave an affirmative answer, as in 2013, acknowledging the need to improve the management of Natura 2000 area. $27 \%$ considers that these actions will have no effect what is a disappointing growth since 2013 the number was $12 \%$, and $22 \%$ chose the option I do not know / I do not answer.

\section{Do you think stopping actions that endanger the species and habitats from the Site could positively influence your life?}

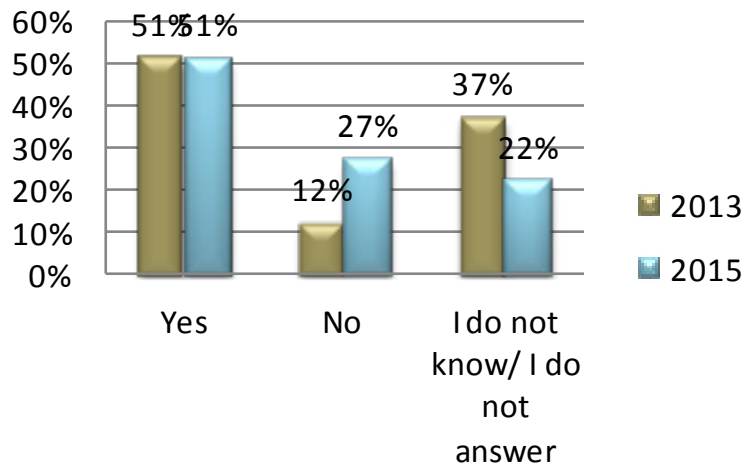

Question number 11 is slightly more complicated but an attempt was made to establish the knowledge related to the definitions of the Natura 2000 network. Between the two sociological surveys can be seen a decrease in the number of those who chose variants $a$ and $b$ and an encouraging increase of those who have chosen the correct response. Unfortunately, remains high number of subjects who chose I do not know/I do 
not answer - 41\%, even if it decreased by $16 \%$ compared with 2013.

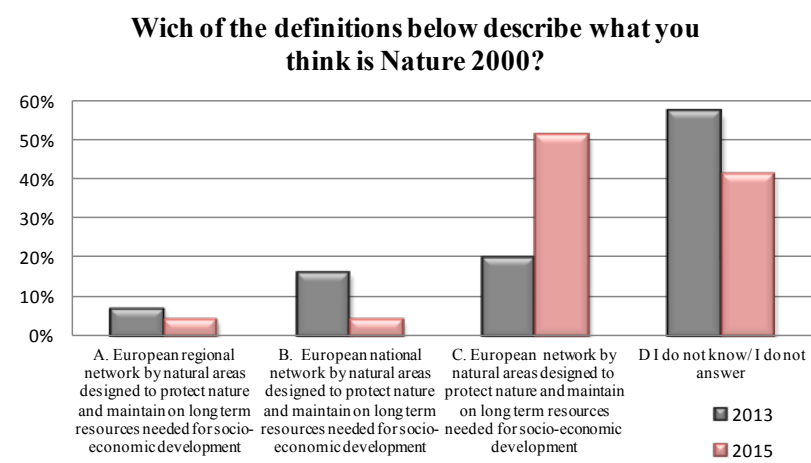

Regarding the interest for a possible involvement in projects that will support the Site as representatives of the local community, it was noticeable a interest in participating in projects to support the Natura 2000 Somesul Rece represented by $62 \%$ of those survived, $20 \%$ are not interested and 18\% opted for the variant I do not know / no answer.

\section{Are you interested in participating in projects that will support the Nature $\mathbf{Q} 2013$ 2000 Someşul Rece Site as local $\quad$ Q2015 community representatives?}

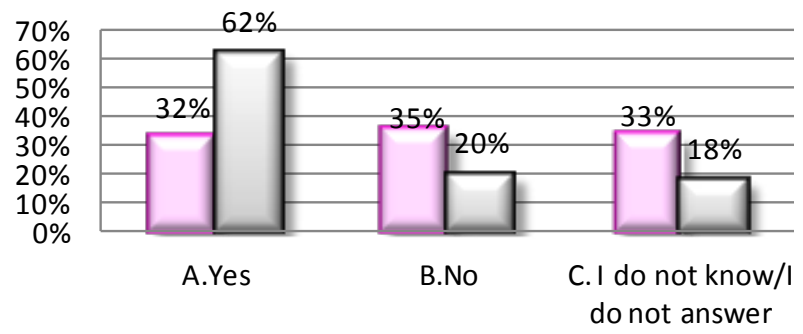

Question number 14 wanted to know the sources of information for citizens in the area and as expected, the television came out first, with a percentage of $54 \%, 2$ percent difference from the 2013 survey, followed by radio in a proportion of $9 \% 11$ percent less than the previous investigation. The remaining percentages were filled with sources such as newspapers, internet or discussions with friends and fellow villagers. $4 \%$ of subjects chose I do not know/I do not answer, but in this situation, the fact that media is occupying the first places shows that is necessary to create other information platform with a much higher credibility.

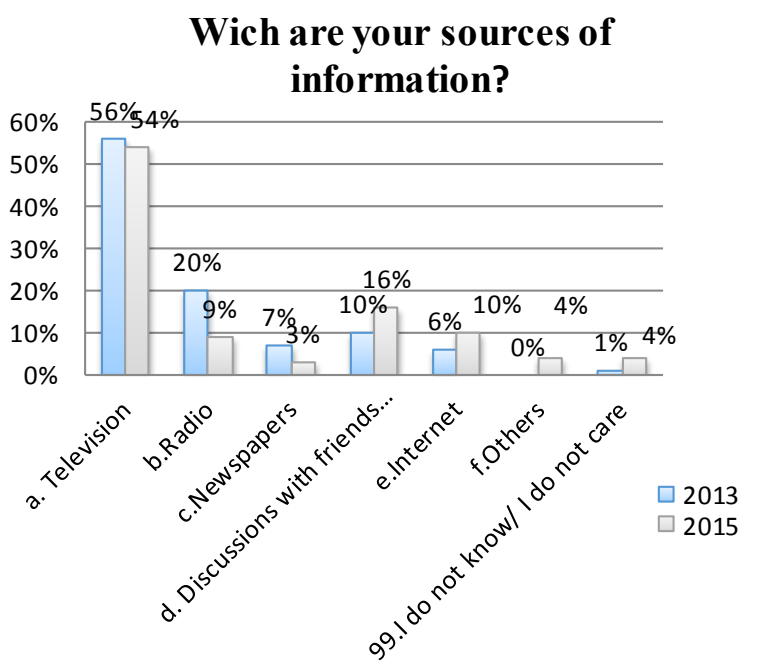

\section{CONCLUSION}

As can be seen in the comparative tables, information stage reached its goal and managed, in a lower or higher percentage to change people's perception vis-a -vis the natural protected areas Natura 2000 and to consider ROSCI0233 Somesul Rece Site as an opportunity to lay the foundations for economic actions leading to prosperity to the residents and develop area, without prejudice the local beauty. It should therefore continue the awareness sessions because there are certain views which must be eliminated from residents mentality, and without a continuation of these sessions, there is a possibility that this project does not achieve all the primary objectives.

Acknowledgments to Sustenable development of Natura 2000 Somesul Rece Site Project POS Mediu 2007-2013.

\section{REFERENCES}

1. ***, (2015) Research Report concerning the nevel of awareness of local communities about Somesul Rece Area.

2. ***, (2013). Sustenable development of Natura 2000 Somesul Rece Site - Grant Application 